\title{
EFFECT OF HUMAN ADIPOSE-DERIVED STEM CELL IN COLLAGEN GEL ON RELATIVE EXPRESSION LEVEL OF VASCULAR ENDOTHELIAL GROWTH FACTOR-A OF DEEP DERMAL BURN HEALING
}

\author{
PUJI SARI ${ }^{*}$, DWI PRATAMI SEPTIARA ${ }^{2}$, HELSY JUNAIDI ${ }^{2}$, LULUK YUNAINI ${ }^{1}$, JEANNE A PAWITAN ${ }^{3}$
}

${ }^{1}$ Department of Biology of Medicine, Faculty of Medicine, Universitas Indonesia, Depok, Indonesia. ${ }^{2}$ Master Program in Biomedical Sciences, Faculty of Medicine, Universitas Indonesia, Depok, Indonesia. ${ }^{3}$ Department of Histology, Faculty of Medicine, Universitas Indonesia, Depok, Indonesia. Email: puji_sari@yahoo.com

Received: 07 December 2017, Revised and Accepted: 17 April 2018

\section{ABSTRACT}

Objectives: The objectives of this research was to measure the relative expression levels of vascular endothelial growth Factor-A (VEGF-A) in the deep dermal burns treated with human adipose-derived stem cell (hADSC) in collagen gel in each observational day (days 7, 14, 21, and 28).

Methods: This study used 20 male Sprague Dawley rats, divided into four groups of observation days. Each rat received three burn injuries and then given different treatments (hADSC in collagen gel, collagen gel, and control). Deep dermal burn injury on the dorsal was made by placing a metal plate with $250^{\circ} \mathrm{C}$ for $15 \mathrm{~s}$. The relative expression of mRNA VEGF-A was determined by RT-qPCR technique and calculated using $2^{-\Delta \Delta C t}$.

Results: On the $7^{\text {th }}$ day, the relative expression level of VEGF-A in the wound treated with hADSC in collagen gel was significantly different from the collagen gel and control group $(\mathrm{p}<0.05)$, whereas the control and collagen gel group was not significantly different. The relative expression level of VEFG-A in wound treated with hADSC in collagen gel, collagen gel only, and control was (mean \pm standard error of the mean) $17.93 \pm 4.37,7.54 \pm 2.63$, and $5.44 \pm 1.59$, respectively. On the next observation days, the result showed that the relative expression level of VEGF-A was not significantly different between the three treatments. The relative expression level of VEGF-A has decreases from day 7 to 28 days. The decrease of VEGF-A relative expression level hADSC in collagen gel group was significantly different on the $7^{\text {th }}$ day to the $21^{\text {st }}$ and $28^{\text {th }}$ days $(\mathrm{p}<0.05)$.

Conclusion: The provision of hADSC in collagen gel increases the relative expression of VEGF-A early in the wound healing process compared to the without a hADSC group.

Keywords: Angiogenesis, Burn injury, Human adipose-derived stem cell, Vascular endothelial growth Factor-A.

(c) 2018 The Authors. Published by Innovare Academic Sciences Pvt Ltd. This is an open access article under the CC BY license (http://creativecommons. org/licenses/by/4. 0/) DOI: http://dx.doi.org/10.22159/ajpcr.2018.v11i7.24161

\section{INTRODUCTION}

Burns are a form of damage and or loss of tissue due to contact with sources that have very high temperatures, chemicals, electricity, radiation, or very low temperatures [1]. Burns become a global health problem because it is one of the main causes of morbidity and mortality. Based on the WHO database, in 2016, is estimated about 265,000 people die from burns each year. Approximately $90 \%$ of cases of burns occur in developing countries. The highest incidence occurred in Africa and Southeast Asia [2]. Burn wound healing is a complex process consisting of an early phase of abrupt energy depletion and necrosis, followed by inflammatory phase, delayed cell death, formation of granulation tissue, matrix formation, and remodeling [3]. The wound healing process begins immediately after injury by releasing various molecular compounds from the blood vessels [4]. Angiogenesis on burn healing process is indispensable because the blood vessels carry oxygen and nutrients to the damaged tissues, carrying immune cells, as well as preparing wound areas for tissue regeneration and repair [5]. There are three growth factors, which play an important role in the formation of blood vessels. They are fibroblast growth factor, vascular endothelial growth factor (VEGF), and angiopoietin-1.VEGF signals are essential for the development of the endothelial and hematopoietic cell. Proliferation and migration of endothelial cells are a marker of the formation of new blood vessels. VEGF is a growth factor that maintains the survival of endothelial cells, angiogenesis inducers, and preserves vascular permeability [6,7]. VEGF proteins include VEGF-A, VEGF-B, VEGF-C, VEGF-D, and placental growth factor. Among these, VEGF-A is the most important protein and plays an important role in the migration and proliferation of endothelial cells $[6,8,9]$. VEGF proteins are secreted by various cell types such as keratinocytes, smooth muscle cells, platelets, neutrophils, macrophages, and fibroblasts, including endothelial cells [10]. Until now, the autograft method is a "gold standard" to replace damaged skin organs in massive burns. The limited source of skin organs from the same individual becomes a problem, especially in massive burns [11]. The application of stem cell therapy is expected to be an efficient solution in the treatment of burns $[12,13]$. Mesenchymal stem cells can be isolated from adult tissue such as cord blood, bone marrow, and fat tissue [14-16]. Stem cells from fatty tissue commonly abbreviated adipose-derived stem cell (ADSC) can produce from waste liposuction patients in beauty clinics or plastic surgery. Transplantation using mesenchymal stem cells in the treatment of burns is require the material as a scaffold to avoid stem cells flowing and wasting away. This material is used to support ADSC. Collagen is an important component in the formation of granulation tissue during the wound healing phase [17]. Human ADSC (hADSC) administration is expected to increase VEGF-A secretion in the healing process of burns.

\section{METHODS}

\section{Study design}

The research protocol has been approved by the Medical Research Ethics Committee FKUI/RSCM, with the protocol number: 17-030261. This research was conducted at Animal Laboratory of Research and Development Center of the Indonesian Ministry of Health, Culture Laboratory of Biology of Medicine - Department FKUI, and Molecular Biology Laboratory of Biology of Medicine - Department FKUI. 


\section{Animal models}

The samples were randomized male Sprague Dawley rats, 10 weeks old. Based on the calculation of the number of samples, this study used 20 rats with 5 rats for each group. Animal models to be adapted in the laboratory for 1 week, kept in 1 rat in 1 cage with underpad base. Meals and drinks were given on ad libitum. The day before the rat treatment was given paracetamol (15 mg/kg BW) dissolved in drinking water, as an analgesic, the administration was continued for 1 week. On the day of rat treatment anesthetized using a combination of ketamine (85 mg/ $\mathrm{kg} \mathrm{BW}$ ) and xylazine (10 mg/kg BW) intraperitoneally [18-20] Each rat will get three burns on dorsal area. The wound is made parallel to the line of the mouse vertebra with a distance of $1 \mathrm{~cm}$ to the right and left side of the vertebral bone; $0.5 \mathrm{~cm}$ below the bone of the scapula, and $2 \mathrm{~cm}$ of vertical wound distance. The metal plate with a temperature of $250^{\circ} \mathrm{C}$ was placed for $15 \mathrm{~s}$ to make deep dermal burn injury on the dorsal. Every day wounds were observed. The wound on the skin will appear round-shaped with a diameter of $10 \mathrm{~mm}$. The same step was carried out so that there were three burns for each rat.

\section{hADSC transplantation}

A total of $1 \times 10^{6}$ hADSC in collagen gel were administered on the $3^{\text {rd }}$ wound. $100 \mu \mathrm{L}$ collagen gel given on $2^{\text {nd }}$ wound and $1^{\text {st }}$ wound not given any treatment (control)

\section{Isolation of RNA from skin tissue burns}

All wounds were daily observed until the sacrificial day of the rat (days $7,14,21$, and 28). RNA from the sample tissue was isolated using the total RNA Mini Kit (tissue). The tissue samples were taken 20-25 mg and fed into a $1.5 \mathrm{~mL}$ microtube containing $400 \mu \mathrm{L} \mathrm{RB}$ Buffer and $4 \mu \mathrm{L}$ $\beta$-mercaptoethanol, then homogenized using micropestle until the tissue was destroyed. Transfer the homogenate into a filter column placed on a $2 \mathrm{~mL}$ tube, then centrifuged at $1000 \mathrm{rpm}$ for $1 \mathrm{~min}$. The filtrate that passes through the filter column will be accommodated in a $2 \mathrm{~mL}$ tube, then transfer the filtrate to a $1.5 \mathrm{~mL}$ microtube add $400 \mu \mathrm{L}$ $70 \%$ ethanol then homogenized.
The mixture transferred to an RB column, which has been placed on a $2 \mathrm{~mL}$ tube and centrifuged at 12,000 rpm for $3 \mathrm{~min}$. The supernatant passing through the RB column was removed, and the RB column was placed back on the $2 \mathrm{~mL}$ tube. Subsequently, $400 \mu \mathrm{L}$ wash buffer was added to RB column and centrifuged at $12,000 \mathrm{rpm}$ for $3 \mathrm{~min}$. The supernatant passing through the RB column was removed, and the RB column was placed back on the $2 \mathrm{~mL}$ tube. Then, add $50 \mu \mathrm{L}$ DNase I solution to the middle of RB column and incubate for $15 \mathrm{~min}$ at room temperature $\left(20-30^{\circ} \mathrm{C}\right)$.

The next step, after incubation $15 \mathrm{~min}$, added $400 \mu \mathrm{L}$ W1 Buffer to RB column and centrifuged at 12,000 for $2 \mathrm{~min}$. The supernatant passing through the RB column was removed, and the RB column was placed back on the $2 \mathrm{~mL}$ tube. Then, add $600 \mu \mathrm{L}$ wash buffer to RB column and centrifuged at 12,000 rpm for $2 \mathrm{~min}$. The supernatant passing through the RB column was removed, and the RB column was placed back on the $2 \mathrm{~mL}$ tube. Perform once again giving $600 \mu \mathrm{L}$ wash buffer to RB column and centrifuged at $12,000 \mathrm{rpm}$ for $2 \mathrm{~min}$. The supernatant passing through the RB column was removed, and the RB column was placed back on the $2 \mathrm{~mL}$ tube. Then to dry the column matrix, the RB column was centrifuged again at $12,000 \mathrm{rpm}$ for $4 \mathrm{~min}$.

Next step, remove RB column from $2 \mathrm{~mL}$ tube and place RB column on sterile $1.5 \mathrm{~mL}$ microtube. Add $50 \mu \mathrm{L}$ RNase-free water to the center of the matrix column and incubate for $3 \mathrm{~min}$ to ensure that RNase-free water was absorbed by the matrix then centrifuged at 12,000 rpm for 3 min to elute the purified RNA. The concentration and purity of RNA were calculated using nanodrop, taken as much as $2 \mu \mathrm{L}$. Total RNA was stored at $-80^{\circ} \mathrm{C}$ for a long time.

\section{Synthesis of cDNA}

Furthermore, RNA was synthesized into cDNA. All materials for this procedure should be thawed and spin down before working on ice $\left(0-4^{\circ} \mathrm{C}\right)$. The first step was to make the Mixture I (DNase I reaction solution), the RNA template used as $6 \mu \mathrm{L}$ mixed with $2 \mu \mathrm{L} 4 \mathrm{x}$ DN Master Mix, then incubated at $37^{\circ} \mathrm{C}$ for 5 min using thermal block. After that,

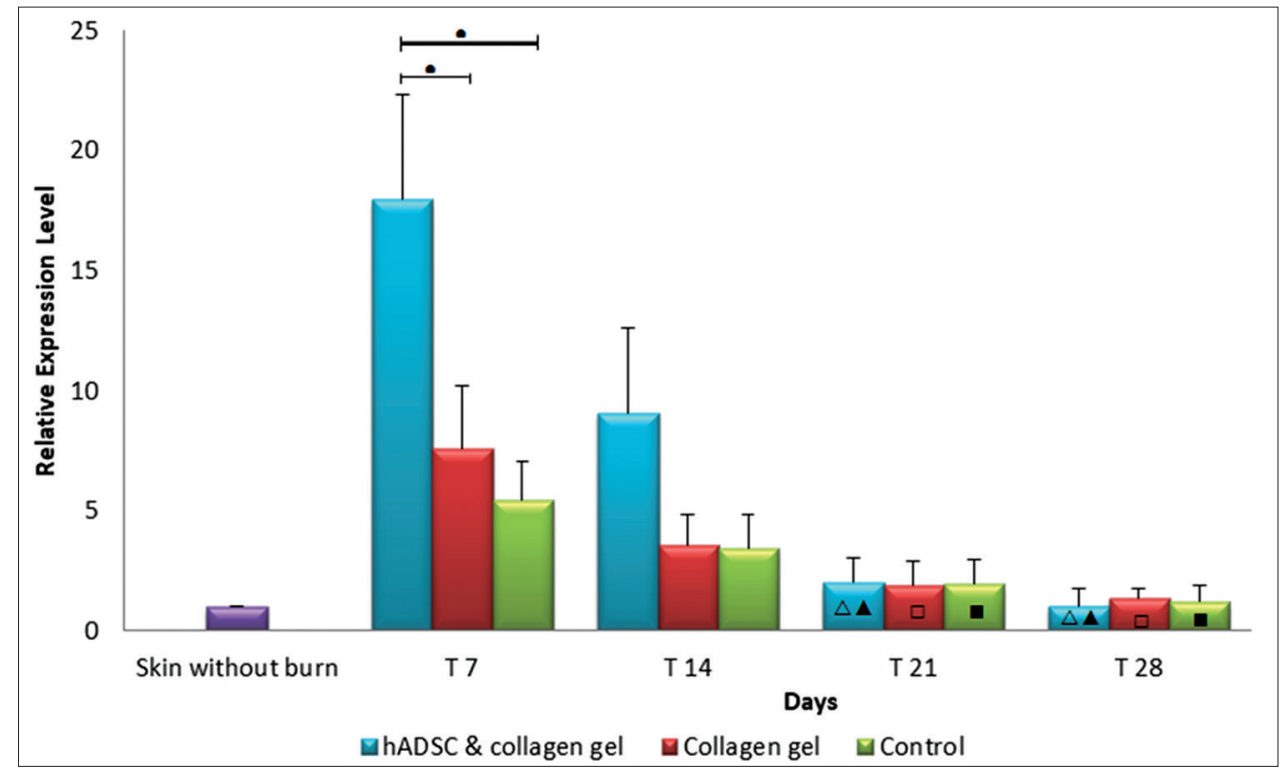

Fig. 1: Average relative expression of vascular endothelial growth Factor-A (VEGF-A). On the $7^{\text {th }}$ day of observation, the relative expression of VEGF-A in skin lesions administered by human adipose-derived stem cell (hADSC) in collagen gel was higher than the collagen gel and control group $(\mathrm{p}<0.05)$. The $14^{\text {th }}, 21^{\text {st }}$, and $28^{\text {th }}$ days of observation resulted in a relatively different level of VEGF-A expression. $\triangle$ Indicates statistically significant difference compared with burn treated hADSC in collagen gel at the $7^{\text {th }}$ day (p<0.05); $\Delta$ Indicates statistically significant difference compared with burn treated hADSC in collagen gel at the $14^{\text {th }}$ day (p<0.05); $\square$ indicates statistically significant difference compared with burn treated collagen gel at the $7^{\text {th }}$ day $(p<0.05)$; and $\square$ Indicates statistically significant difference compared with control at the 7 th day $(p<0.05)$ 
add $\times 5 \mathrm{RT}$ master Mixture II and incubate at $37^{\circ} \mathrm{C}$ for $15 \mathrm{~min}, 50^{\circ} \mathrm{C}$ for $5 \mathrm{~min}$, and $98^{\circ} \mathrm{C}$ for $5 \mathrm{~min}$. There was found a solution of cDNA with a final volume of $10 \mu \mathrm{L}$. The cDNA solution was stored at $-20^{\circ} \mathrm{C}$ for storage in the long term.

\section{VEGF gene expression test}

The material used for the measurement of the relative expression of VEGF-A gene mRNA is THUNDERBIRD ${ }^{\circledR}$ SYBR $^{\circledR}$ quantitative PCR (qPCR) mixture. The primer used is specially designed to obtain the primary target gene sequence as shown in Tables 1 and 2 :

The volume of each reactant is $20 \mu \mathrm{L}$ with components of $4.4 \mu \mathrm{l} \mathrm{H} \mathrm{H}_{2} \mathrm{O}$, $0.6 \mu \mathrm{L}$ primary forward, reverse primer, $0.4 \mu \mathrm{L} \times 50 \mathrm{ROX}$ reference dye, $10 \mu \mathrm{L}$ THUNDERBIRD ${ }^{\circledR}$ SYBR $^{\circledR}$ qPCR master, and $4 \mu \mathrm{L}$ cDNA template. The solution fed into the Lightcycler capillary. Next, centrifuge at 3000 rpm for $15 \mathrm{~s}$. The solution fed into the polymerase chain reaction PCR machine by following the cycle protocol.

\section{Statistical analysis}

Statistics analysis used SPSS computer software for Windows (Version 17.0, SPSS Inc., Chicago, IL). The relative expression of VEGF-A in the wound that given hADSC in collagen gel, collagen gel, and control at $7^{\text {th }}$, $14^{\text {th }}, 21^{\text {st }}$, and $28^{\text {th }}$ day was analyzed by one-way ANOVA. The decrease in VEGF-A relativity expression from $7^{\text {th }}$ to $28^{\text {th }}$ days in various treatments was analyzed by one-way ANOVA. Statistically significant values were defined as ${ }^{*} \mathrm{p}<0.05$

\section{RESULTS}

\section{Comparison of the relative expression level of VEGF-A}

At the $7^{\text {th }}$ day observation, there are significant differences between hADSC in collagen gel group with control and collagen gel group $(p<0.05)$, while between control group with collagen gel group was not significant different $(p>0.05)$. The average relative expression level of VEGF-A in the hADSC group in collagen gel was higher than the collagen gel and control group. On $14^{\text {th }}, 21^{\text {st }}$, and $28^{\text {th }}$ days observation, there were no significant differences between the three treatments. On the day 14 of observation, the relative expression level of VEGF-A of the hADSC in collagen gel group was higher than control and collagen gel group. The average relative expression level of VEGF-A on all treatments at days 21 and 28 is almost as same (Fig. 1).

\section{Decrease in relative expression level of VEGF-A by observation} days

The relative expression level of VEGF-A was analyzed on $7^{\text {th }}, 14^{\text {th }}$, $21^{\text {st }}$, and $28^{\text {th }}$ days. In all treatments group, there was a decrease in the relative expression level of VEGF-A from day 7 to 28. Calculation of relative expression was done using Livak method. Hence, the average relative expression (mean \pm standard error of the mean [SEM]) of VEGF-A mRNA on the $7^{\text {th }}$ day by giving hADSC in collagen gel $17.93 \pm 4.37$; collagen gel $7.54 \pm 2.63$ and controls $5.44 \pm 1.59$. There was a decrease in VEGF-A mRNA expression the following day. On the day 14, an average expression of VEGF-A mRNA was obtained on wound treated with hADSC in collagen gel of $9.08 \pm 3.53$; collagen gel $3.57 \pm 1.27$; and controls

Table 1: Primer of mRNA VEGF A

\begin{tabular}{ll}
\hline Primer & Sequences $\left(\mathbf{5}^{\prime} \rightarrow \mathbf{3}^{\prime} \mathbf{)}\right.$ \\
\hline Forward primer VEGF A & TGGACCCTGGCTTTACTGCT \\
Reverse primer VEGF A & CTTCACCACTTCATGGGCTTC \\
Forward primer actin beta & GATCTGGCACCACACCTTCT \\
Reverse primer actin beta & GGGGTGTTGAAGGTCTCAAA \\
\hline
\end{tabular}

$3.54 \pm 1.36$. Furthermore, at the day 21, the expression of VEGF-A mRNA in all three treatments was seen to be almost as same. Expression of VEGF-A mRNA in wound given hADSC in collagen gel 2.00 \pm 1.02 ; collagen gel 1.88 \pm 1.00 ; and control $1.94 \pm 1.00$. On the day 28 , there was also a decrease in VEGFA mRNA expression from the previous day in all three treatments. Expression of VEGF-A mRNA in hADSC in collagen gel $1.03 \pm 0.71$; gel collagen $1.38 \pm 0.37$; and control $1.19 \pm 0.68$.

\section{DISCUSSION}

In this study, VEGF-A mRNA expression examination started on the $7^{\text {th }}$ day after burn. The results showed an increase in VEGF-A mRNA expression on the $7^{\text {th }}$ day compared to calibrator (VEGF-A mRNA expression in normal skin-no burns). This can be causes of the effect of hADSC in the collagen gel on the burn tissues by paracrine mechanisms. In addition, the increased expression of sharp VEGF-A mRNA on the $7^{\text {th }}$ day was also influenced by the activity of inflammatory cells producing VEGF-A. VEGF is produced by many types of cells that participate in the healing of burns such as keratinocytes, mast cells, macrophages, fibroblasts [10], endothelial cells, smooth muscle cells, platelets, and neutrophils. VEGF secretion by these cells is induced by the hypoxic conditions that occur due to burns $[10,21]$.

VEGF-A mRNA expression subsequently decreased from the $14^{\text {th }}$ to $28^{\text {th }}$ day. On the $21^{\text {st }}$ and $28^{\text {th }}$ days, VEGF-A mRNA expression was almost same to the value of the calibrator. This is because the condition of wound tissue is approaching the homeostatic state. The pattern of decreased expression of VEGF-A mRNA on the $7^{\text {th }}$ to $28^{\text {th }}$ day in this study is similar to Brown et al. study. The results of Brown et al. showed increased VEGF on the $3^{\text {rd }}-7^{\text {th }}$ day after wound injury. Then there was a decrease in the $13^{\text {th }}$ day and after 3 weeks did not increase compared to normal [21].

The comparison of expression of VEGF-A mRNA in each treatment showed a significant difference between hADSC in collagen gel with collagen gel and control at the $7^{\text {th }}$ day. The expression of VEGF-A mRNA in burn tissue treated with hADSC in collagen gel was higher than without hADSC. This suggests that there is an hADSC in the collagen gel roles to the burn tissue. There are several possible mechanisms for the effects of hDASC on these burns. The provision of hADSC has a direct effect on the damaged tissue by differentiating it into vascular endothelial cells, and VEGF transcription becomes more numerous. hADSC may also give paracrine effect to cells surrounding wound thus affecting rat cells to increase VEGF transcription. Then, the presence of collagen gel can also act as a medium conducive for maintaining cells or tissue exposed hot can survive.

This is reinforced by the results of research conducted by indicating that ADSC administration to the wound showed an activated fibroblast phenotype and resulted in the recruitment of endothelial cells and macrophages increased in the wound area $[22,23]$. It is known that the cells play a role in VEGF secretion. Therefore, it is possible that hADSC has a paracrine effect on rat niche cells thus affecting the amount of VEGF secretion during the wound healing phase. In addition, other studies showed that allogenically administratin of stromal vascular fractionincreases VEGF secretion on the 10 day, VEGF secretion in the treatment group was higher than control [24].

The results of the study of VEGF-A mRNA expression in burns treated with hADSC in collagen gel on the $14^{\text {th }}$ day have shown no significant difference compared with collagen gel and control. However, it still has a higher expression value in treatment with hDASC in collagen gel ( mean \pm SEM), hADSC in collagengel $=9.08 \pm 3.53$; collagen gel $=3.57 \pm 1.27$; and control treatment $=3.54 \pm 1.36$. This suggests that until the $14^{\text {th }}$ day,

Table 2: Cycling protocol

\begin{tabular}{lllll}
\hline Program & Pre-incubation & Amplification & & \\
\hline Target $\left({ }^{\circ} \mathrm{C}\right)$ & 95 & 95 & 57 & 72 \\
Hold (hh:mm:ss) & $00: 03: 00$ & $00: 00: 30$ & $00: 00: 30$ & 12 \\
\hline
\end{tabular}


hADSC still give the influence to burn tissue, but it has less effect. On the $14^{\text {th }}$ day, it is estimated to have entered the proliferation phase. The inflammatory cells that secrete much VEGF early in the healing period may have decreased. On the $21^{\text {st }}$ and $28^{\text {th }}$ days, VEGF-A mRNA expression in all three treatments was no significant difference. The condition of the burned tissue has reached homeostatic conditions, so there is no induction of VEGF secretion as in hypoxic conditions like in the beginning wound healing process.

Then, collagen gel provides a three-dimensional (3D) structure for hADSC to remain in the wound area and help the inflammatory cells to get to the wound area early in the injury time. In this study, there is no examination by an electron microscope to see the collagen 3D gel structure. Even in the process of wound healing, there is also an extracellular matrix that will provide an adhesion framework for the cell to organize the growth, movement, and differentiation of cells in it [25]. A study by Karimi et al. showed no significant differences in wound healing parameters observed among groups given ADSC by injection with untreated groups [26]. studies that use biomaterials to created 3D structures showed better wound healing result $[27,28]$. This means that the use of collagen gels as the scaffold is required in administration hADSC to the wound tissue.

\section{CONCLUSION}

The provision of hADSC in collagen gel increases the relative expression of VEGF-A in the early of wound healing process compared to the without hADSC. There was a decrease in the relative expression level of VEGF-A on the $7^{\text {th }}$ day until the $28^{\text {th }}$ day.

\section{ACKNOWLEDGMENTS}

This study was funded by post graduate research grant 2017 , Contract No: 550/UN2.R3.1/HKP.05.00/2017 and No: 0705/SK/R/UI/2017 from Directorate of Research and Community Service (DRPM), Universitas Indonesia.

\section{CONFLICTS OF INTEREST}

All authors have none to declared.

\section{REFERENCES}

1. Moenadjat Y. Luka Bakar: Masalah dan Tatalaksana. $4^{\text {th }}$ ed. Jakarta: Balai Penerbit FKUI; 2009. p. 1-13.

2. Yang Z. Chinese Burn Surgery. London: Springer Dordrecht; 2015. p. $1-481$

3. Biradar S, Rasal V, Raygude KS. Evaluation of wound healing activity of Cyperus rotundus essential oil. Int J Pharm Pharm Sci 2012;4:4-6.

4. Werner S, Grose R. Regulation of wound healing by growth factors and cytokines. Physiol Rev 2003;83:835-70.

5. Busuioc CJ, Popescu FC, Mogoșanu GD, Lascăr I, Pirici I, Pop OT, et al. Angiogenesis assessment in experimental third degree skin burns: A histological and immunohistochemical study. Rom J Morphol Embryol 2011:52:887-95.

6. Dulak J, Józkowicz A, Łoboda A. Angiogenesis and Vascularisation: Cellular and Molecular Mechanisms in Health and Diseases. London: Springer Dordrecht; 2013. p. 416.

7. Rosida SS, Khotib J. The increasing of VEGF expression and re- epithelialization on dermal wound healing process after treatment of banana peel extract (Musa acuminata, Colla). Int J Pharm Pharm Sci 2014;6:427-30.

8. Shibuya M. Vascular endothelial growth factor (VEGF) and its receptor (VEGFR) signaling in angiogenesis: A crucial target for anti- and proangiogenic therapies. Genes Cancer 2011;2:1097-105.

9. Koch S, Claesson-Welsh L. Signal transduction by vascular endothelial growth factor receptors. Cold Spring Harb Perspect Med 2012;2:1-21.

10. Johnson KE, Wilgus TA. Vascular endothelial growth factor and angiogenesis in the regulation of cutaneous wound repair. Adv Wound Care 2014;3:647-61.

11. Singh A, Shenoy YR. Skin substitutes: An Indian perspective. Indian J Plast 2012;2:388-95.

12. Lee DE, Ayoub N, Agrawal DK. Mesenchymal stem cells and cutaneous wound healing: Novel methods to increase cell delivery and therapeutic efficacy. Stem Cell Res Ther 2016;7:37.

13. Morton LM, Phillips TJ. Wound healing update: Acute wound healing. Semin Cutan Med Surg 2012;31:33-7.

14. Jin HJ, Bae YK, Kim M, Kwon S, Jeon HB. Comparative analysis of human mesenchymal stem cells from bone marrow, adipose tissue, and umbilical cord blood as sources of cell therapy. Int J Mol Sci 2013;1:17986-8001.

15. Balaji S, Keswani SG, King A, Crombleholme TM. The role of stem cells in wound angiogenesis. Adv Wound Care (New Rochelle) 2014;3:614-25.

16. Dominici M, Le Blanc K, Mueller I, Slaper-Cortenbach I, Marini F, Krause D, et al. Minimal criteria for defining multipotent mesenchymal stromal cells. The international society for cellular therapy position statement. Cytotherapy 2006;8:315-7.

17. Brien FJO. Biomaterials and scaffolds every day thousands of surgical procedures are performed to replace. Mater Today 2011;14:88-95.

18. In A, Ucsf AT, Formulary M. Institutional Animal Care and Use Committee (IACUC) Anesthesia and Analgesia in Laboratory Animals at UCSF; 2012;100(X):20-3.

19. Yaman I, Durmus AS, Ceribasi S, Yaman M. Effects of Nigella sativa and silver sulfadiazine on burn wound healing in rats. Vet Med (Praha) 2010;55:619-24

20. Akbari H, Fatemi MJ, Iranpour M, Khodarahmi A, Baghaee M, Pedram MS, et al. The healing effect of nettle extract on second degree burn wounds. World J Plast Surg 2015;4:23-8.

21. Bao P, Kodra A, Tomic-canic M, Golinko MS, Ehrlich HP, Brem H. The role of vascular endothelial groth factor in wound healing. J Surg Res 2010;153:347-58.

22. Koenen P. Adipose-derived stem cells in wound healing: Recent results in vitro and in vivo. OA Mol Cell Biol 2013;1:81-6.

23. Hong SJ, Jia S, Xie P, Xu W, Leung KP, Mustoe TA, et al. Topically delivered adipose derived stem cells show an activated-fibroblast phenotype and enhance granulation tissue formation in skin wounds. PLoS One 2013;8:e55640.

24. Yan H, Xing X, Li H, Yan H, Li X, Zhu J. Role of stromal vascular fraction in severe burn wound healing process. Biomed Res 2017:28:1237-41

25. Sorg JM. Wound repair and regeneration. Eur Surg Res 2012;49:35-43.

26. Karimi H, Soudmand A, Orouji Z, Taghiabadi E, Mousavi SJ. Burn wound healing with injection of adipose-derived stem cells: A mouse model study. Ann Burns Fire Disasters 2014;27:44-9.

27. Linero I, Chaparro O. Paracrine e ect of mesenchymal stem cells derived from human adipose tissue in bone regeneration. PLoS One 2017:10:1-12

28. Majidi M, Haghighipour N, Bayati V. Healing potential of mesenchymal stem cells cultured on a collagen-based scaffold for skin regeneration. Iran Biomed J 2012;16:68-76. 